\title{
DEPARTMENT OF REPORTS AND DOCUMENTS
}

\author{
I. CRITICAL AND INTERPRETATIVE \\ Editwd ay John A. Fairlit \\ Profossor of Political Scionce, Universily of ILinois
}

The City Milk Trade. ${ }^{-}$Most people think that the milk question is new in America, that it appeared not over twenty years ago, but really it began to make itself felt in the big cities at an earlier period. Thus, in 1859 the office of milk inspector was established in Boston; in 1870 the board of health of Providence investigated the milk supply of that city; and in 1871 the board of health of Washington looked into that of the federal city. But in a sense the public is right, for the regular collection and analysis of milk samples did not become common in American cities until the period from 1885 to 1890 . It seems probable that at about this time the family cow disappeared and dairymen found it necessary to locate so far from their trade that they found it difficult to deliver milk in good condition and had lost personal contact with their customers. At all events the efforts of those who were trying to keep milk supplies pure were almost wholly in the direction of attempting to stop watering, skimming, and other forms of sophistication. Such work was certainly necessary, if the records are to believed, for this kind of cheating was common, but it was an attempt on the consumer's pocketbook rather than on his life. This was forcefully brought to public attention by Sedgwick and Batchelder in 1890 , by the publication of the results of their bacteriological study of the milk supply of Boston. The large number of germs found amazed people and prepared the way for new methods of controlling milk supplies.

A few years later the town of Mont-

1 See Nationat Municrpal Review, vol. 1, pp. 71 and 700 ; vol. 11, pp. 313 and 509 . clair, N. J., suffered from a severe epidemic of milk-borne typhoid fever, and in consequence established a board of health on thoroughly modern lines that ever since has stood as an example of what a board of health should be. It chanced that the health officers appointed by this board were pupils of Sedgwick; so, for this reason, and, perhaps, because a milk epidemic begot the board, it has given much attention to the milk question. In bettering local conditions less emphasis was laid on chemical tests than on dairy inspection and on bacterial counts, with the result that milk was improved by correcting conditions that prevailed on the farms whence it came. The work was educational both to the dairymen and the public, for inspectors spent much time at the farms and the annual reports of the board, both in pictures and words, told exactly the conditions at the several farms that supplied the town. This sort of story is familiar now, but then it was new, consequently the reports had a wide circulation, so that Montclair methods were widely copied and, in fact, in forms adapted to the needs of other communities, came into general use.

That Dr. Henry L. Coit, when he originated certified milk in 1893, made a contract for its production with a Montclair dairyman, Stephen Francisco, was of great help to the board, for there was already established in the field a sanitary dairy that was successful enough to impel other dairies to copy its methods and that for some time had been educating people to the value of clean milk. The idea of having milk certified by a medical milk commission spread. Certified dairies are established in many places in the 
United States, and everywhere exert a similar influence to that of Montclair.

At about the same time that the work of Sedgwick and Batchelder appeared, the agricultural experiment stations began to evince interest in dairy bacteriology and in the production of clean milk. Conn of Connecticut and Russell of Wisconsin were the first workers in the field, and Conn's investigation of the bacterial content of the milk supply of Middletown, Conn. was one of the earliest studies of the kind. The dairy bacteriologists of the experiment stations soon focused their attention on cream, butter and cheese, so that until recently the city milk trade has been more influenced by medically trained bacteriologists than by bacteriologists of agricultural experience, but the latter type of man is again becoming interested in city milk supplies and may be expected to be active in the next few years.

Among those having a more general interest, philanthropists stand out prominently. Nathan Strauss, for example, has provided funds for the distribution of pasteurized milk to poor mothers, thereby doing an act of charity and making way for pasteurizing milk by endorsing its use and acquainting the public with it. He has a shoal of imitators, who have made it possible in many different cities to maintain milk stations where good milk can be procured or sick babies at reasonable rates. Other moneyed men, feeling that they could best help by improving methods of production and distribution, have provided funds for elaborate studies in these fields.

With so many interested in the milk problem it was natural that it should be discussed in societies of various sorts. Thus, the American Public Health Association, the International Milk Inspectors Association, the Dairy Instructors Association, the American Association of Medical Milk Commissions, the New New York Milk Committee, and a host of similar organizations have been active in formulating methods of laboratory procedure, or in devising score cards, or in considering methods to protect the dairy business, or in proposing legislation.

Many other forces have been at work, but these seem to be the principal ones; each is powerful, and each has reacted differently on dairying. What each has done, and what may be expected of each may be profitably considered.

The societies have been the center where the differences of experts and questions of policy have been thrashed out, where lines of attack were laid out, and determination to support or oppose proposed legislation was reached. It is not likely that these functions will change or that the influence exerted by the associations will be greatly different from what it now is.

The milk charities too will probably continue as they are, though there will very likely be more of them. They will teach mothers the value of milk and how to use it. The scientific investigations that have been made possible by private gifts may be expected to continue to be of great importance.

Medical milk commissions and the dairies they have certified have been helpful in many ways. In the first place, they have furnished milk that was known to be clean and as safe as raw milk can possibly be. This has been a boon to infants and invalids. They have demonstrated that no amount of care can protect milk absolutely from infection; that raw milk always may be unsafe. They have demonstrated good methods, but they have shown that it is possible to apply such expensive machinery to the dairy business and to impose on it such restrictions that profits reach a vanishing point and thereby have warned the commercial man that so far and no farther can he go. The milk produced by these dairies is a valuable asset to a community but is one that by reason of its cost is available only to the rich, therefore it can solve the milk question for only a few.

Physicians perhaps more than others appreciate the value of pure milk, but their interest has, perhaps, been stimu- 
lated by certified dairies. The doctors have contributed valuable papers both from the school and in the medical press. Tuberculosis, pasteurization, and the reduction of infant mortality called forth their best efforts. They have helped locate the cause of epidemics, and have appeared at meetings where questions of milk supply were under discussion. The certified dairies will multiply, but it is hardly to be expected that they will serve a much larger proportion of the communities wherein they operate than they now do. Their influence will be much the same, but the dairy world has absorbed their doctrine and it is unlikely they will add much thereto.

The agitation of the milk question by boards of health has been conducted from the city man's view point; that is, its object has been to secure a low infantile morbidity rate and to protect the populace from those diseases that are spread in milk. A large degree of success has been attained. Incidentally it has been discovered that the milk question has many aspects, that the amelioration of conditions involved is most intricate and touches big investments of capital. The interests expressly affected by the activity of boards of health are those of the dairyman and of the contractor, middleman or distributor, as he has been variously called, but indirectly other large interests such as the railroads are concerned. The position of the boards of health has been difficult, for they have been charged by the farmers with ignorance of farm conditions, by the railroads with imposing impossible orders as regards icing and other matters, and by contractors with the promulgation of regulations that were unnecessary, arduous and expensive. In other words, at times they have had to face the opposition, open and covert, of large financial interests; it is also true that, speaking by and large, these interests want good conditions in the dairy business, and by their cheerful support of regulations of the boards have secured their quick application with a minimum of friction.
In reaching the standards proposed by boards of health both dairymen and contractors have had to introduce costly machinery, improve their plants, and adopt more expensive methods of handling milk. Moreover, the big contractors in order to conduct their business properly have had either to establish systems of inspection and laboratories of their own, or else tó have this work done in the large commercial laboratories that are to be found in the great cities. The latter custom has resulted in creating a class of experts who are vigilant to protect their clients' interests and to introduce improvements that will cut down expenses both in the city and the country. It follows that both dairymen and contractors have been drawn into the discussion of dairy problems, and that through granges, milk dealers associations, and other organizations of various sorts they have exerted an influence on the price of milk and on the laws enacted to govern its production and distribution. Boards of health then have had great influence, direct and indirect, which they will probably continue to exert, for they are working in the consumers' interest and have the support of a powerful public opinion; but it is likely that in the future the experimental and inspection work will be checked up more closely than heretofore by other investigators.

The agricultural experiment stations naturally see the farmer's position and, perhaps, only less clearly the contractors. For years station men have been investigating and collecting data on dairying. They know, as no one else does, that the modern dairy farmer has large sums of money invested in his business and that he must be a highly trained man in order to succeed. They appreciate fully that the profits in dairying are not easy and that only careful management can reap them. Consequently, the stations have labored zealously to get dairymen to adopt economical rations, to weed out non-productive or robber cows, to pay attention to breeding, and to be biologically clean, so that the products 
may be wholesome and of good flavor, thereby insuring the best market prices. They know that dairying must pay a reasonable profit to be sound, hence the stations have tried to make the dairymen efficient and have protested when regulations have been proposed that sounded good and entailed expense, but yielded no adequate benefit. The work of the stations will grow in importance, for at present it is the hope of improving farm conditions that holds out the brightest prospect for a solution of the milk question.

\section{University of Illinois. \\ Horatio N. Parker.}

State Tax Commissions.-At last we are developing a tax literature strictly of our own. "Made in Germany" is a term no longer applicable to theoretical and practical works on public finance for the use of the American student. We can thank our tax commissions and National Tax Association for this happy deliverance.

In looking over the reports of our permanent tax commissions and tax commissioners, the reviewer is impressed with the six "Firsts" which are now to be added to the list of reports. The six newcomers are Arizona, Colorado, Louisiana, North Dakota, Ohio and Wyoming. The old ones are, of course, Alabama, Connecticut, Indiana, Kansas, Maryland, Massachusetts, Michigan, Minnesota, New Jersey, New York, North Carolina, Oregon, Texas, Vermont, Washington, West Virginia, Wisconsin-a total of twenty-three in all.

A gross defect, easily avoidable, found in several of these reports, is the lack of a table of contents or of an index. Indeed Alabama, Indiana, and Wyoming have neither index nor table of contents. Surely in this modern day of scientific report making, these flagrant defects are wholly inexcusable. Another weak point in several reports is the printing of a great mass of statistical matter without comment or explanation. The best re- ports subordinate the statistical data to a small part of the report, and preferably, to an appendix.

Certain familiar recommendations, so venerable as to be hoary-bearded, are now reiterated in the newer reports. The three chief ones are these: (1) The failure of the personal property tax makes it necessary to end or mend this barbarity without delay; (2) A centralized assessment must be had, if any improvement is to be realized. A state with the countyassessor system even advises that this system be supplanted by a direct state assessment; (3) Constitutional limitations preserve defects in our present system and preclude benefits of other systems.

Among the newer things securing attention and some emphasis, are uniform municipal accounting, tax maps for cities, and a minimum tax on intangibles. These are all sound recommendations. Great interest is being shown in the Wisconsin income tax, although most commissions suspend judgment on it. And for the first time the single tax is receiving serious and impartial treatment.

In my judgment, two reports stand out above the rest in merit, especially for the student in municipal finance. These two are the Wisconsin and the Minnesota report. These deserve specific discussion.

An excellent analysis of the income tax is given in the Wisconsin report. This tax is shown to be urban rather than rural in its incidence. It is clearly a "city tax" and falls most heavily on the largest cities. It is a revenue-producer; is not inquisitorial in operation; and is a very good substitute for the personal property tax.

Chapter six of the Wisconsin report deals with uniform municipal accounting. The act creating the permanent tax commission in 1905 provided that the commission should investigate accounting and financial methods of the towns, cities, villages, counties, and other public 
offices, and should formulate and prescribe a uniform system of accounting. This was not done. In 1909 a resolution was passed directing the commission to investigate the question of public expenditures. A volume on state finance was accordingly published. Chapter 523 , laws of 1911, required more definitely the formulation of a system of municipal accounting. Such a system is to be installed "at the request of any town, village, city, or county." The system is to be as uniform as practicable. Under this statute the commission has completed and installed a system of public accounting in three counties, four cities and villages, and nine towns, and has audited accounts in three of these cities. Applications are now pending for the installation of a system of accounting in ten additional municipalties, two of which have also requested an audit.

This work is done at the expense of the municipality.

The installation of systems of accounts for counties, towns, and villages and for small cities is comparatively simple. The financial affairs (but not the records) of these districts are usually in excellent condition. "On the other hand," says the report, "the financial affairs and methods of the larger cities have been exceedingly haphazard as a general rule. In many cases the plainest provisions of the statute have been violated with respect to sinking funds and other important financial matters."

The pay-as-you-go spirit is exceedingly pronouced in the country districts. The precise reverse is the common practice in the cities. "Instead of showing a disposition to pay for improvements out of revenues, the common disposition appears to be to borrow for all improvements and frequently to borrow for current expenditures. Thus, while generally speaking, our towns and counties are acquiring fixed property in values amounting to large sums with comparatively little debt to offset them, our cities seem disposed to incur large debts, off- setting to a very large extent, whatever capital assets the city may own."

"A prime requisite of any accounting system is that there shall be a proper audit of every receipt and of every expenditure by proper officials," says the commission, and yet this check is commonly wanting.

Bonded debt of municipalities is a potential menace. "This debt is growing rapidly and too often bonds are refunded instead of being retired at maturity."

The serial plan of paying bonds is now successfully applied in cases where the state school money is loaned to municipalities. This plan avoids the sinking fund pitfalls.

Chapter twelve of the Minnesota 1912 report (pages 165-180) is entitled "taxation of land values," and contains a remarkably clear and adequate discussion of the tax systems of western Canada. In Canada there are no constitutional restrictions on taxation, and hence tax systems in the various provinces and cities have been worked out to fit industrial conditions. It is the single tax which receives the fullest treatment in this chapter.

Winnipeg derives its public revenue from (1) real estate; (2) business; and (3) franchise taxes. (1) Land is assessed at full value, buildings at two-thirds. (2) The business tax takes the place of a personal property tax, and is levied on the supposed rental value of the buildings.

Saskatchewan cities derive their revenue from (1) real estate, (2) business, and (3) income taxes. Buildings are now taxed, but will not be taxed in a few years. Business taxes are levied at so much per square foot of floor space, the rates being classified (50 cents for sash and door factories, $\$ 8$ for banks, etc.).

In Calgary, Alberta, land is assessed at full value, and buildings are to be entirely exempt by 1914 .

Edmonton, the capital of Alberta, is the only city of importance in Canada that has adopted the single tax system in 
its entirety. A tax of land values alone is the only tax levied in that city. "The city has had a marvelous growth in the past few years," says the report, but whether or not such growth has been due in part to its tax system is a question of some dispute. That it is giving general satisfaction, is evidenced by the fact that nearly every resident of the city is an ardent single taxer.

In Vancouver, B. C., there is a provincial tax on personal property and incomes, but the city itself uses a land tax. It was the first Canadian city to exempt all buildings and improvements. The experiment has been successful.

For Minnesota the conclusions on the single tax, are as follows: To the average owner and occupant of a home or a farm the change would probably not mean much one way or the other. The elimination of personal property taxes however, would undoubtedly add somewhat to the tax burdens of speculators and owners of idle property.

$$
\text { James E. Borre. }
$$

University of North Dakota.

Housing and City Planning. LFourth National Conference on City Planning.? In spite of the fact that an increasing amount of attention was paid by the Conference to political, economic and social problems, anyone familiar with the activities of the European cities cannot but feel that the full significance of these phases of city planning is not realized by the experts in this country. It is true that engincering and landscape questions are of large importance, but they are, in the last analysis, matters of technical or aesthetic detail whose solution is not difficult. Of greater significance are the questions of housing, of sanitation and hygiene, of transportation and terminal facilities, the legal

\footnotetext{
1 See also revtew of "Recent City Planning Reports," by Charles Mulford Robinson, Natronal Munictpal Ravinw, vol. 11, p. 160.

isee National Montcipal Review, vol. l, p. 728.
}

difficulties and many others of a similar nature.

These matters were all discussed to a certain extent by the Conference, and yet the important question of excess condemnation did not receive the attention which it merited. This is especially remarkable, for a careful study of the city planning situation in this country will reveal that it is just this matter which promises to be a real obstacle in the way of future progress in city expansion.

Another question which the Proceedings suggest is that of state administrative control, which might be vested in the public service commissions. To be sure, city planning in the United States has not advanced sufficiently to require such control, but this is a factor which should be kept in mind with a view to averting the embarrassing situations in which the cities in other countries have been put.

\section{University of Illinois.}

Julios Gomber JR.

Jersey City." A report of "Suggested Plan of Procedure," prepared for the Jersey City plan commission differs markedly from many other city planning reports in presenting a comprehensive consideration of all phases of the city's problems. It has been prepared, not by one, but by several experts working constantly together-an engineer, an architect and a social worker. At the beginning of the report are discussed the methods and principles of the work of the experts; and at the close there is a summary of facts and recommendations, with an analysis of the relative importance of various items, from which is worked out an order of inquiry. Such a procedure program seems to offer distinct advantages as a first step in city planning work. It costs comparatively little, and should save a good deal of expense in working out the more detailed items.

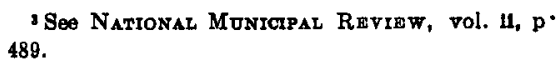


Newark. In a similar report for $\mathrm{New}-$ ark many of the detailed programs have been carried out, including studies of street traffic, the market problem and the use of the water front. The housing survey and report, by Dr. James Ford, of Harvard University, includes a comprehensive discussion of present conditions, with more specific consideration of proposed legislation, law enforcement, replanning old districts and planning new areas. The conclusions of this report are in favor of a permanent city plan commission for metropolitan Newark, and also for the organization of a permanent housing association or committee, which will create and represent the enlightened public opinion of the community. A similarly comprehensive recreation survey was in charge of $\mathrm{Dr}$. Seymour Barnard of the Parks and Playgrounds Association of Brooklyn.

Housing Bibliography. The Chicago School of Civics and Philanthropy has published a valuable bibliography of housing problem literature in central Chicago libraries. This was prepared in anticipation of the housing exhibition at the City Club during the month of March.1 The lists of titles are classified under the following heads: Bibliographies, periodicals and collections, general works on housing and related subjects, city planning and garden cities, public regulation of housing and city planning, hygiene of towns and houses, architecture of tenements and small residences, land question as it affects housing and garden patches.

Street Improvements in Chicago. The committee on down town streets of the Chicago Association of Commerce has published A Brief List of Suggestions to Public Improvement Associations, by Louis A. Dumond, engineer of the committee. This calls attention to the opportunitics of local improvement organizations, the importance of maintenance of street pavements, adequate street lighting, and the cleaning of

1 See National Municipal Revinw, vol. 11, p. 497 . streets, back yards and vacant lots; and discusses more fully some details of paving construction, with reference to different kinds of paving materials.

New York Freight Terminals. A brief report with maps, showing plans for freight terminal systems at South Brooklyn and West Side Lower Manhattan, was submitted by Calvin Tomkins, Commissioner of Docks of New York City, under date of September 12, 1912.

Financial Reports.-The annual report of the New York City department of taxes and assessments, for the year ending March 31, 1912, besides the usual statistics and comparative statments for a number of years, includes two appendices-one on factors of value of new buildings and explanation of land value maps, and one on the taxation of personal property in the state of New York.

The fortieth annual report of the commissioners of accounts of New York City, for the year 1912, illustrates the value of these officers to the mayor in his administrative control of municipal offcers, in the regulation of departmental accounts and methods and also in reports on sundry other matters. The efficiency staff, organized in 1911, has been conducting an investigation into conditions in the office of the president of the borough of Queens. In addition to the regular examination of receipts and disbursements, special examinations were made on a variety of subjects, including billboard advertising, public charities, municipal ferries, probation officers and theft of supplies.

Report No. 4 of the Baltimore, Md., bureau of state and municipal research presents a discussion of balance sheets for the eity of Baltimore for 1911 and 1912, with exhibits showing the status of loan and income funds.

The report of Comptroller Taussig of St. Louis, for the year 1911-1912, includes, in addition to a siummary report, detailed statements of the funded debt, the financial transactions for 1911-1912, 
estimates for 1912-1913, and a list of exhibits presenting comparative financial statements for a series of years.

The report of the city auditor of Los Angeles, for the year 1911-1912, in addition to the data for that year, includes comparative tables of receipts and disbursements for five years and also a number of tables of miscellaneous information relating to Los Angeles and its municipal government.

A novel and commendable practice, inaugurated by the comptroller of Schenectady, N. Y., is the publication of brief financial reports during the course of the fiscal year. On July 1, 1912, a report was issued showing budget expenditures compared with allowances for the first six months of the fiscal year; and in October of the same year a report was published showing the activities of the department from January 1.

Civil Service Reform.-The proceedings of the annual report of the $\mathrm{Na}$ tional Civil Service Reform League, held at Milwaukee, Wis., December 5 and 6 , 1912 , includes the report of the joint committee of this League and the $\mathrm{Na}$ lional Municipal League on the selection and retention of experts in municipal office, and a paper on methods of removal in the Chicago and Illinois services by Robert Catherwood and William B. Hale.

The seventeenth annual report of the board of city service commissioners of Milwaukee, Wis., contains a copy of the city service act, the rules of the commission and the statistical report of the chief examiner and secretary. The report of the commission covers less than half a page; and the principal staternents are that the department has been conducted on a business basis and that the board has worked harmoniously and with impartiality.

The tenth annual report of the civil service department of Los Angeles, Cal., also presents statistical data, some correspondence and official opinions, charter provisions, civil service rules and a list of the positions in the city service.

The annual report of the board of of civil service commissioners of $\mathrm{New}$ Orleans, $L a$., notes that the new commission government law for that city does not disturb "the organic principles" of the civil service law. The report also includea financial and other statistics, the civil service law and rules, instructions to applicants and specimen examination papers.

All of the three foregoing municipal reports indicate a purely routine and mechanical performance of the work of such commissions; and there is nothing to indicate the effectiveness of the merit system or its results in the municipal service.

The efficiency division of the civil service commission of Chicago has published an outline report of its work from 1909 to 1912 , under such headings as segregated appropriations and expenditures, standardized employment and uniform salaries, effective organization and efficiency control and departmental inquiries. With this is printed an analysis of employment and departmental organization charts for the city of Chicago, as of March 1913.

Social Service.-Municipal Charities in Philadelphia. With the advent of Mayor Blankenburg's administration in Philadelphia, and with the approval of the mayor, a committee on municipal charities was formed, consisting of more than one hundred citizens for the purpose of endeavoring to secure a release for the city from contracts for two charitable institutions and to prepare a reasonably comprehensive plan for the development of the city's institutions. This committee was organized with an executive committee and eleven sub-committees on various classes of dependents. Under date of February 3, 1913, this committee has issued a report, with a series of subcommittee reports, which embody a survey of the city's existing system of char- 
ities, the various groups of dependents, and recommendations for a more comprehensive system of dealing with the respective classes of dependents. These recommendations include changes in the administrative organization of municipal charities and a revised classification of institutions and of beneficiaries of such institutions.

Virginia. The fourth annual report of the Virginia state board of charities and corrections is published under the title "Social Service in Virginia." It includes an account of the administration of the state charitable and correctional institutions and also of county and city institutions, with statistics and recommendations,

The proceedings of the Virginia Conference on Charities and Corrections, held at Danville, January 26-28, 1913, includes papers on municipal health departments, the city housing problem, and the work of the Richmond juvenile court.

Seattle, Wash. The annual report of the juvenile court for 1912 has been published in a small booklet, with a report on the clinical classification of delinquent children according to causative pathology.

Park Reports. - Chicago. The public parks in Chicago are administered by several distinct authorities, mutually independent of each other. One result of this situation is the lack of any comprehensive report of the park facilities as a whole, and a marked contrast in the style and effectiveness of the reports of the different park authorities. The forty-fourth annual report of the West Chicago park commissioners is an elaborate and expensive publication, printed on heavy calendered paper, with numerous illustrations. The report of the special park commission, appointed under the authority of the council, is much less expensive, but is a well printed pamphlet with several good illustrations, giving a satisfactory account of the small parks and playgrounds under the control of this commission. The Lincoln park commissioners publish only a small leaflet presenting a financial summary, but with no information as to the operation or development of this portion of the Chicago parks.

Detroit. The twenty-third annual report of the department of parks and boulevards is also an illustrated pamphlet printed on good paper, including both financial statements and information as to the management and development of the park system. Special attention may be called to the increased attention to the care of street trees, the inauguration of an automobile service to Belle Isle (the principal city park) and a financial summary by years since the establishment of the department.

The Pennsylvania Chestnut Tree Blight Commission has published two bulletins on the chestnut blight disease and the treatment of ornamental chestnut trees affected with the blight disease.

Water Supply.-Illinois. The proceedings of the fifth meeting of the Illinois Water Supply Association is a substantial volume of 277 pages, containing some forty papers on various problems connected with public water supplies. The association includes both municipal water works and private companies, and the secretary is the director of the state water survey. The meeting was held at the University of Illinois, March 11 and 12 , and among the papers the following may be noted: "Legal Aspects of Financing Municipal Water Works," by E. V. Orvis, commissioner of public property, Waukegan, Ills.; "Vital Statistics and Water Supplies," by Paul Hansen, state water survey; and the "Appraisal of Water Works Properties," by Douglas A. Graham, consulting engineer, Chicago. Other papers dealt with a variety of technical engineering and sanitary problems, and with local condi- 
tions in a number of Illinois cities, such as Moline, Rock Island, Rockford, Pana and Danville.

Industrial Water Charges. The bureau of water in the Philadelphia department of public works has been publishing a water supply educational series of booklets. No. 2 is a study of industrial water charges, dealing principally with charges in excess of $\$ 200$. This presents the facts of the existing situation without suggesting improvements; but it is hoped that the study of these data will lead the city towards a more equitable system of levying water charges on industrial plants and other large water users.

Reports of Civic Associations and Educational Institutions Received.-Portland, Ore. Municipal Association, for year ending September 30, 1912.

Tax Association of Alameda County (Cal.) Suggestions for Consideration in Preparing a Charter for Alameda County. February, 1913.

The Civic League of St. Louis: Eleventh Year-Book, 1911-12.

Massachusetts Civil Service Association: Report of the Executive Committee, Boston, 1912.

Citizens' Federation of Hudson County, N. J.: First Annual Report of the Secretary, May, 1912-May, 1913; The New Jersey Legislature of 1913.

City Club of Chicago: Annual Reports of Civic Committees, 1912-13, in the City Club Bulletin, June 28, 1913.

National Consumers League: Thirteenth Report, for the year ending January $19,1912$.

Fairmount Park Art Association: Forty-first Annual Report of the Board. of Trustees, 1913.

Commission of Fine Arts: Message from the President Transmitting Report for the Fiscal Year ending June 30, 1912.

Training School for Public Service, conducted by the New York Bureau of Municipal Research: Annual Report, 1912.
Chicago School of Civics and Philanthropy: Alumni Register, 1903-1913; Summer School, 1913.

Central Purchase and Distribution of Supplies.-Under date of March 15, 1913, Comptroller Prendergast of New York City presented to the board of estimate and apportionment a report submitting a plan of a proposed system for the central purchase and distribution of supplies for the city, with copies of the forms necessary to carry the system into effect. The detailed plan was prepared by W. Richmond Smith, with the coöperation of experts in the department of finance. This plan was developed from that of the Canadian Pacific Railway, which purchases four times as much as the city of New York.

There are in the city government of New York one hundred and twenty different departments, bureaus and offices vested with the power to purchase supplies. The proposed plan contemplates the centralization of the purchase of all supplies through a general purchasing agent, and their distribution to the various offices from a general city storehouse, operated as a clearing house for all except perishable supplies and coal, wood and forage. ${ }^{1}$

Government Bulletins.-Various bureaus of the United States government issue from time to time bulletins of information and advice on municipal problems. Public health Bulletin No. 54, issued by the U. S. Public Health Service, gives an analysis of the laws and regulations of the various states on the organization, powers and duties of health officers. This traces brielly the historical development, and describes more fully the present organization of state and local heal th authorities. An appendix contains the text of the various state and

\footnotetext{
iSee National Municipal Review, vol. if, p.
} 221 
territorial health laws, and head notes of judicial divisions relating to such laws.

Circular 185 of the Bureau of Animal Industry gives a brief account of state and municipal meat inspection and municipal slaughter houses.

Bulletin 49 of the Bureau of Mines is a discussion of city smoke ordinances and smoke abatement in the United States, by Samuel B. Flagg.

Public Lectures in New York City.The report of Supervisor Henry M. Leipziger on the public lectures given under the direction of the department of education of New York City shows that in the year 1911-12, these lectures were given at 174 centers, to 5573 audiences, aggregating an attendance of $1,000,190$. The report gives in detail the list of lecture centers, a classified list of lectures and examination questions. The various lectures are grouped in four main divisions: literature, history, sociology and art; general and applied science; descriptive geography; and lectures in foreign laguages (Italian, Yiddish and German). In the sub-division of social subjects are several series of lectures on municipal topics, notably on municipal courts and the work of various departments of city administration.

Wisconsin Fire Insurance Investigation.-A joint committee of the Wisconsin legislature of 1911 has submitted a report of an investigation of fire insurance with recommendations for changes in the laws. The investigation and report deal with the principles of fire insurance, fire insurance companies, the policy contract, rates and methods of rate making, methods and expenses of the business, fire prevention, supervision and state insurance. The recommendations are summarized under thirty-three heads and fifteen bills are submitted. The most important recommendations are for the review of fire insurance rates by the insurance department, the consolidation of the fire marshal and oil inspector with the insurance department, and a legislative committee to prepare a state building code and city planning law.

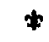

Schenectady Contract Specifications.The bureau of engineering of the Schenectady, N. Y., department of public works has issued a pamphlet of 56 pages containing detailed information in regard to contracts for paving in that city. This includes instructions to bidders, form of proposal, form of contract and specifications, for paving and incidental work. These are significant because prepared by the Socialist administration of this city. The commissioner of public works recommends that a guarantee bond be not required, holding that under the new form of contract good pavements can be secured by proper inspection and supervision, and that a guarantee is superfluous and an added expense with no added value.

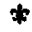

Special Libraries.-Recent numbers of Special Libraries contain the following bibliographical lists bearing on municipal problems.

February, 1913: Select List of References on Fire Prevention; Public Utility References.

March, 1913: Selected References on Markets and Marketing.

April, 1913: List of Uniform Accounts formulated by companies, associations and state commissions.

May, 1913: Select List of References on Scientific Management and Efficiency, Subdivision on government.

Sewage Disposal in New York.-No. 6 of the preliminary reports of the metropolitan sewerage commission of New York is a study of the collection and disposal of the sewage of the lower Hudson, lower East River and Bay division, No. 
7 , in the same series, presents the critical reports of the Dr. Gilbert J. Fowler of Manchester, England and Mr. John D. Watson of Birmingham, England on the projects of the metropolitan sewerage commission. This agrees in advocating the construction of main drainage channels to carry off the main sewage of lower New York into the Atlantic Ocean.

Cleveland Street Railways.-A pamphlet entitled "The Essentials of Street Railway Regulation in Cleveland" has been issued from the office of the city street railroad commissioner of that city. This contains a digest of the provisions of the ordinances under the terms of which the surface lines of Cleveland are operated, with summarized monthly re- ports of the Cleveland Railway Company, and a skeleton statement of the street railroad commissioner's control over the expenditures of the company. ${ }^{1}$

Suppression of Noise.-A paper on the "Suppression of Unnecessary Noise," by Edward S. Morse of Salem, Mass., read under the auspices of the Ninth International Otological Congress, in Boston, August 14, 1912, has been republished in pamphlet form.

The Bulletin of the Medical and Chirurgical Faculty of Maryland for January, 1913 , is devoted to the anti-noise crusade, which has been actively undertaken by the anti-noise committee of the Baltimore City Medical Society. 630. 